DOI: $10.5604 / 01.3001 .0010 .8646$

\title{
DISTORTIONLESS SIGNALS TRANSFER THROUGH A WIRE MEDIA METASTRUCTURE
}

\author{
Dmytro Vovchuk, Serhii Haliuk, Leonid Politanskyy \\ Yuriy Fedkovych Chernivtsi National University, Department of Radio Engineering and Information Security
}

\begin{abstract}
In the paper the development of the components of communication means is considered based on the wire metastructures. This approach is novel and quite promising due to the metamaterials provides new opportunities for the radio engineering devices such as antennas, absorbers etc. First of all it makes possible decreasing of the dimensions of devices while the characteristics stay the same or better. Here the artificially created metastructure that consists of parallel metallic wires and characterizes by a negative electric permittivity was investigated. The possibility of broadband power transfer of electromagnetic waves was demonstrated. Also, at first time, the investigation of possible signal distortions due to wave propagation through the wire medium (WM) slab was performed via analyzing of spectral characteristics. The obtained results allow applying of WM to power transfer in wide frequency range (not only at frequencies of Fabry-Perot resonant) and enhancement of weak source propagation as well as to antennas constructions due to the absence of signal distortions. One of the promising applications of such structures is the possibility of realizing of flexible screens with nanometer thickness and high resolution.
\end{abstract}

Keywords: wire medium, signal transfer

\section{TRANSMISJA SYGNAŁÓW BEZ ZNIEKSZTAŁCEŃ PRZEZ METASTRUKTURE PRZEWODOWA}

\begin{abstract}
Streszczenie. W artykułe omówiono rozwój komponentów komunikacyjnych opartych na metastrukturach przewodowych. Proponowane podejście jest nowe $i$ obiecujace, ponieważ metamateriały zapewniaja nowe możliwości dla urządzeń radiotechnicznych, takich jak anteny, pochłaniacze itp. Przede wszystkim dotyczy to możliwości zmniejszenia zasięgu urządzeń, podczas gdy ich charakterystyki pozostaja niezmienione, a nawet się poprawiaja. $W$ artykule badana jest sztucznie wytworzona metastruktura, składająca się z równoległych przewodników metalowych i charakteryzująca się wartościami ujemnymi stałej dielektrycznej. Została opisana możliwość jej wykorzystania do szerokopasmowego przesyłania fal elektromagnetycznych. Ponadto, po raz pierwszy zbadano obecność możliwych zniekształceń sygnałów przesylanych przez strukturę za pomoca analizy charakterystyk widmowych. Uzyskane wyniki pozwalaja na wykorzystanie struktury równoległych przewodników do przesyłania sygnatów w szerokim zakresie częstotliwości (nie tylko na częstotliwościach rezonansowych Fabry-Perot) oraz do poprawy sygnałów o niskiej mocy, a także w konstrukcjach antenowych z powodu braku zniekształceń sygnałów. Jednym z obiecujacych zastosowań takich konstrukcji jest możliwość ich zastosowania do elastycznych ekranów o grubości kilkudziesięciu nanometrów o wysokiej rozdzielczości.
\end{abstract}

Słowa kluczowe: środowisko przewodowe, transmisja sygnałów

\section{Introduction}

Metamaterials are one of the most perspective materials to the development of the modern devices, such as waveguides and antennas, radio locators, transmission lines, absorbers, reflectors, metamirrors, lenses $[2,9,13]$ etc. In general, metamaterials are effectively homogeneous artificial materials with unusual and useful electromagnetic properties [8]. This class of materials characterizes by negative value of electric permittivity and/or magnetic permeability $[10,11]$ and includes a large group of artificial electromagnetic structures. One of them is the wire metamaterials that present optically dense array of aligned metal wires or rods embedded into dielectric matrices [5, 7].

Wire medium (WM) is one of the kinds of the wire metamaterials consisting of a two- or three-dimensional rectangular lattice of low-loss wire grids and in the case of $2 \mathrm{D}$ WM this structure is the array of parallel metal wires with length $L$, diameter $2 r$ and lattice period $a$ (Fig. 1).

The WM structure is known for the effective energy transfer at the frequencies of Fabry-Perot resonances which wavelengths are corresponds to the length of structure wires. This property is very useful for modifications of antennas [1] and near-field imaging $[3,6]$ whereas the case of operation in wide frequencies range was impossible. However, in the case of narrow band electromagnetic wave propagation a signal source was directly placed in front of an interface of the WM slab. Therefore, in the works $[4,12]$ the possibility of broadband power transfer using WM slab was considered and the idea was that an embedded source of electromagnetic signal into the WM construction (between wires) provides the damping of Fabry-Perot resonances and supports expanding of operation frequencies.

Therefore, the goal of this paper is to demonstrate the possibility of broadband power transfer of electromagnetic energy the wire media construction and investigate the possible distortions of propagation harmonic and complex signals.

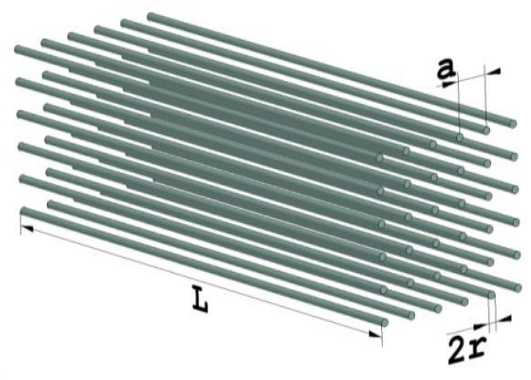

Fig. 1. The metamaterial that consists of parallel metallic wires with length $L$, wires diameter $2 r$ and lattice period $a$, so-called wire medium

\section{Broadband power transfer through the wire media slab}

The schematic structure of the investigated system is shown in Fig. 2a. The system consists of two rectangular (164 by $82 \mathrm{~mm})$ metallic waveguides (input and output) separated by an air gap $l=90 \mathrm{~mm}$. The experiment included both the power transfer of electromagnetic energy through the empty space and using WM slab (length of wires is $L=100 \mathrm{~mm}$ ) between waveguides.

To provide the broadband regime the WM slab was inserted inside each waveguide into a certain depth (5 $\mathrm{mm}$ from each side) that supported near-field interaction of the WM slab with source and the WM slab with transmitter. Thus, the aim of the performed investigation was the comparison of two kinds of power transfer without and with using of the metastructure.

The effectiveness of broadband power transfer was proven by the simulation (Fig. 3) and experimental (Fig. 4) investigations that were performed in $[4,12]$ via scattering $S_{21}$-parameters estimation. The averaged values of enhancement 2.5 and 2.0 in the frequency range from 1 to $2 \mathrm{GHz}$ were reached for simulated model and experimental setup respectively. 


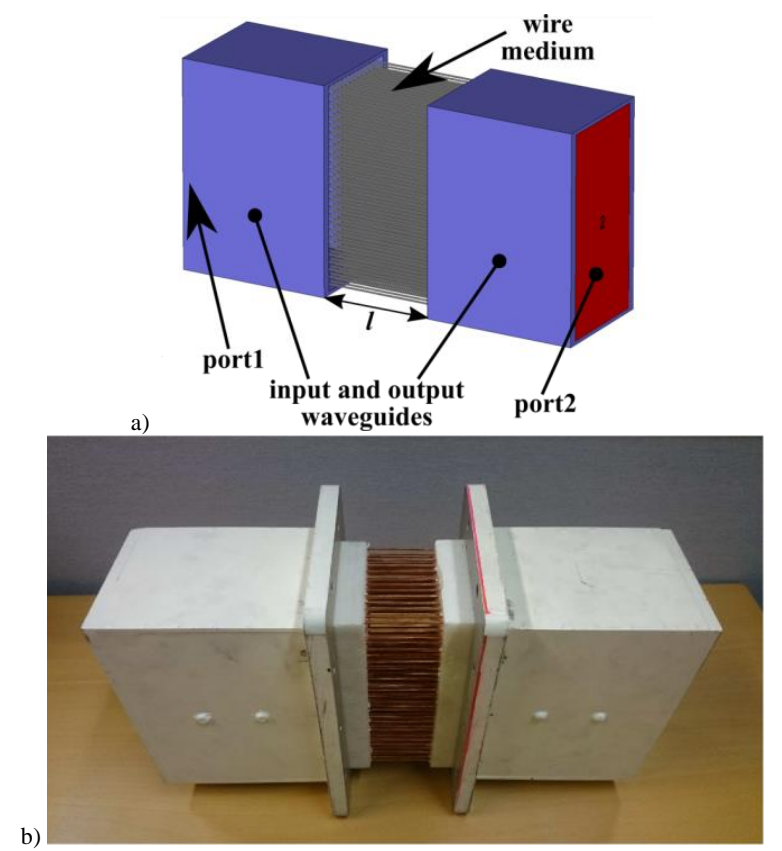

Fig. 2. The investigated system of two waveguides separated by an air gap that is filled by a copper WM structure: $a$ - simulated and $b$-experimental setups

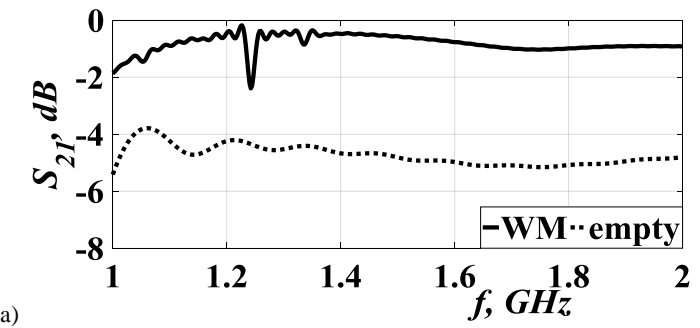

a)

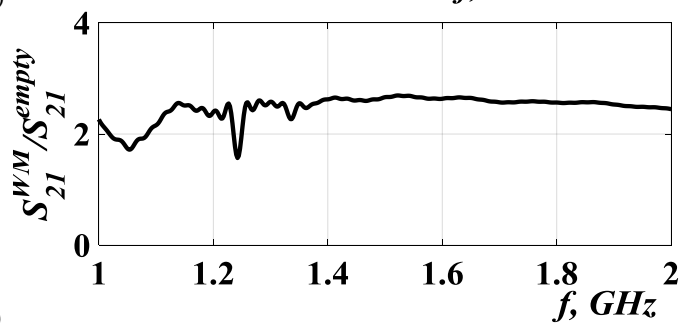

b)

Fig. 3. The simulated reflection parameters $\left(S_{21}\right)(a)$ and obtained enhancement $\left(S_{2 I}{ }^{W M} / S_{21}{ }^{\text {empty }}\right)(b)$ without (dashed plot) and with (solid plot) using WM structure
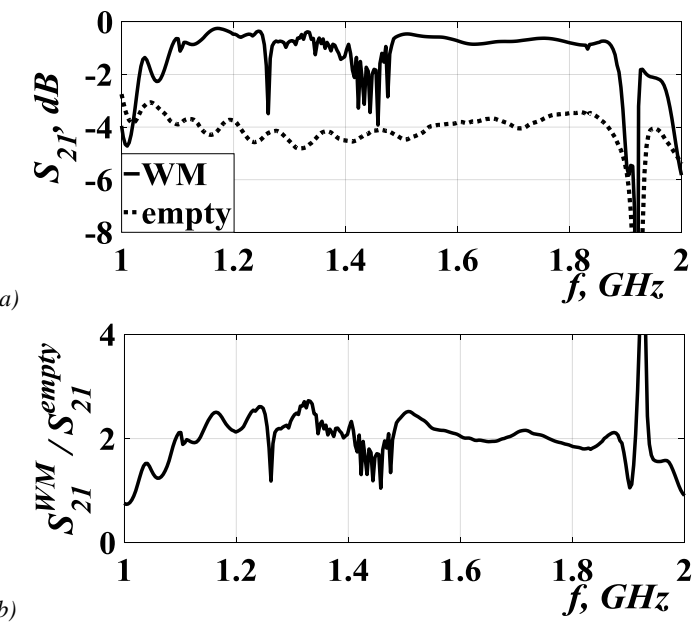

\section{Spectra characteristics of transferred signals through the WM metastructure}

However, from obtained results can be only concluded about the possibility of the power transfer of electromagnetic waves with different modes. In this case we cannot say exactly about the waveform and the response of the WM slab to the input signal but that is very important when the signal accuracy must be satisfied. For example, in the deterministic chaos theory both the broadband and accuracy are required.

For the purpose of possible signal distortions that can be introduced by the WM structures the investigation of the harmonic and chaotic signals transfer through the WM slab were carried out and their spectra characteristics were analyzed by simulation and experiment.

\subsection{Simulation results}

The simulation investigation was performed using already introduced system in Fig. 2a. Port 1 was used as a signal generator and port 2 as a receiver. For the first experiment the transfer of harmonic signal was investigated. The operation signal frequencies were picked up beyond the Fabry-Perot frequencies of the WM slab. Therefore, for presentation in this work for harmonic signals propagation with frequency $2 \mathrm{GHz}$ were shown as the results. As one can see from Fig. 5a and b the spectra characteristics of input and output signals contains only one spectral component. It confirms that the investigated metamaterial is a linear structure.

For the next simulation the complex signal was used as the input signal of Port 1 . The spectra characteristic of the input signal includes five components at $1.7,1.75,2,2.1$ and $2.3 \mathrm{GHz}$. As a conferment of the previous simulation investigation, the output signal was not distorted that is confirmed by comparison of spectra characteristics of input and output signals (Fig. 6a and b). The obtained results show the broadband effect without nonlinear distortions.

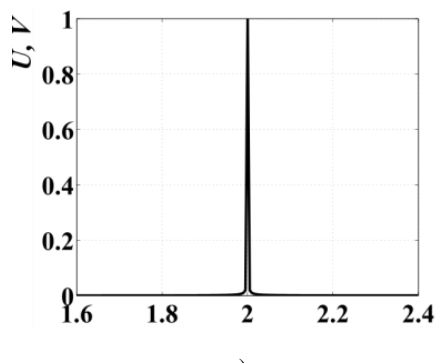

a)



b)
Fig. 5. The simulated spectral characteristics of the input (a) and output (b) harmonic signals transferred through the WM metastructure



a)

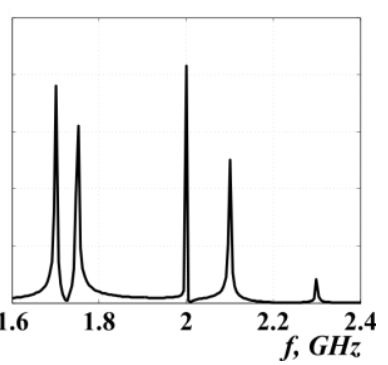

Fig. 6. The simulated spectral characteristics of the input (a) and output (b) complex signals transferred through the WM metastructure

Fig. 4. The experimentally obtained reflection parameters $\left(S_{21}\right)(a)$ and achieved enhancement $\left(S_{21}{ }^{W M} / S_{2 I}{ }^{e m p t y}\right)(b)$ without (dashed plot) and with (solid plot) using WM structure 


\subsection{Experimental results}

For the experimental investigation the system displayed in Fig. $2 b$ was realized but in spite of the S-parameters investigation in the previous section the signal generator was used as the source of harmonic signal and the spectrum analyzer was exploited for the received signal analysing. The investigation was separated into two stages which included harmonic signal transfer through the closed waveguide transmission line (it allows to estimate the possible distortions from the WM construction) and through the air gap between two waveguides coupled by the WM structure as is shown in Fig. $2 b$ (it allows to confirm the obtained in $[4,12]$ results for the possibility of the enhancement power transfer).

Since the transfer of the electromagnetic signals via a waveguide line is almost lossless and without distortions it is possible to investigate the influence of the WM slab on wave propagation and possible wave degradation.

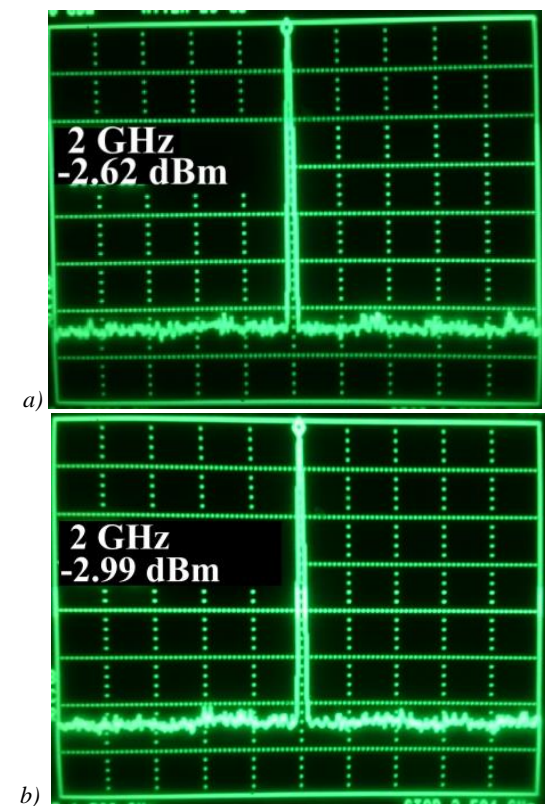

Fig. 7. The spectral characteristics of the harmonic signals received by the output waveguides in the case of: $a$-empty waveguide and $b$-embedded WM slab

To perform this kind of experiment the manufactured WM slab of $30 \mathrm{~mm}$ length $10 \mathrm{~mm}$ lattice period of copper wires was embedded inside the closed waveguide line as shown in Fig. 2. The investigated frequencies of the harmonic signals were picked up different from the Fabry-Perot resonances of the used WM slab. Therefore, the experimental spectral characteristics of the received harmonic signals for the propagation through the empty waveguide and in the case of using of the WM structure are shown in Fig. 7a and b respectively at the frequency $2 \mathrm{GHz}$. One can see that in the first case the signal power has decreased from 1 (the initial power of harmonic signal) to $0.55 \mathrm{~mW}$ (the power of received harmonic signal) which correspond on 0 and $-2.62 \mathrm{dBm}$. In the case when the WM structure is embedded into the waveguide the power of the received signal is $0.50 \mathrm{~mW}$ $(-2.99 \mathrm{dBm})$ and any additional spectral components are absent. It means that the structure does not impact on signal propagation and waveform.

For the next experiment the metal grid with mesh period $10 \mathrm{~mm}$ was manufactured and inserted into the input waveguide in front of the WM slab interface in order to imitate the evanescent wave propagation (Fig. 8). Using the WM metastructure allows enhancing the signal power from $0.0047 \mathrm{~mW}(-23.26 \mathrm{dBm})$ to $0.32 \mathrm{~mW}(-4.94 \mathrm{dBm})$ that are shown in Fig. 9a and b respectively. It means that using the WM slab it is possible to recover the propagation signal without distortions almost to the initial shape.

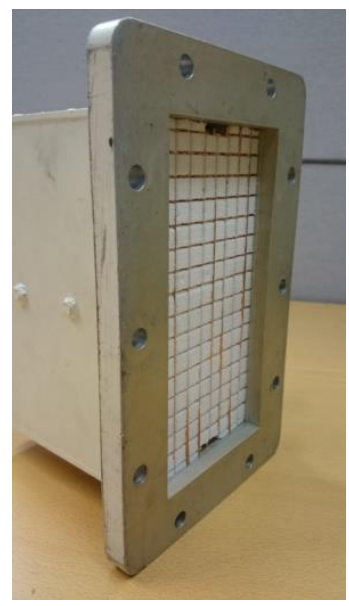

Fig. 8. Metallic grid with mesh period $10 \mathrm{~mm}$ embedded into the input waveguide to provide the enhancement wave propagation

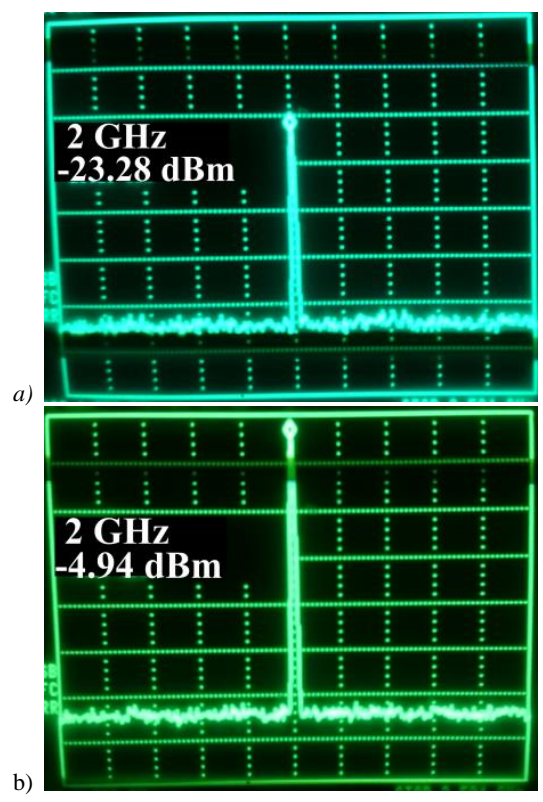

Fig. 9. The same plot as in Fig. 7 for the case when the metallic grid is embedded into input waveguide Port1

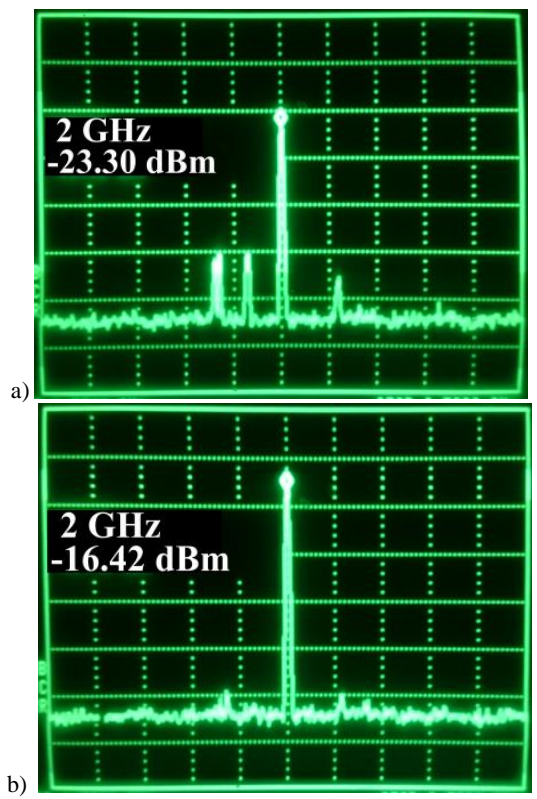

Fig. 10. The same plot as in Fig. 7 and 9 for the case when the waveguides is located one in front of another with distance $90 \mathrm{~mm}$ between their apertures 
To investigate the enhancement of harmonic signal transfer through the air gap between the transmitter and receiver two waveguides were placed one in front of another with distance $90 \mathrm{~mm}$ between their apertures as shown in Fig. 2b. The air gap causes the scattering of electromagnetic energy that correspond the low value of the signal power $0.0047 \mathrm{~mW}(-23.3 \mathrm{dBm})$ and the presence of additional spectral components at the frequencies $1.87,1.93$ and $2.12 \mathrm{GHz}$ due to wave reflection from the output waveguide edges as well as wave interference (Fig. 10a).

The usage of the WM slab allows to enhance the harmonic signal power transfer in approximately 4.85 times $(-16.42 \mathrm{dBm})$ as well as the additional spectral components are absent due to the near-field interaction between the metastructure and the waveguides (Fig. 10b). It proves the obtained result in $[4,12]$ and demonstrates the possibility of the evanescent harmonic signal transfer via the suggested WM metastructure without any distortions at the frequencies different from the Fabry-Perot ones.

\section{Conclusion}

The WM structure that consists of parallel metallic wires (Fig. 1) was considered to show the possibility of broadband power transfer. For simulation and experimental studying the system that consists of two waveguide ports allocated one in front of another with air gap between them was carried out for this purpose (Fig. 2). As a result the enhancement approximately $2.0 \ldots 2.5$ times was achieved for the frequency range $1 \ldots 2 \mathrm{GHz}$.

For the investigation of possible distortions from the WM structure the same setup was exploited and two cases were considered. To study the structure impact to the signal propagation the WM structure was embedded inside the closed waveguide line and it was found that the nonlinear distortions are excluded. The investigation of signal transfer through the free space using WM slab has proven the ability of the metastructure to enhance the evanescent signals and prevent the distortions due to possible reflections, wave interference etc.

The results of our investigation can be useful for the applications of enhancing and controlling heat radiation in thermophotovoltaic devices, signal transfer without nonlinear distortions, broadband communication systems including deterministic chaos signals and, as a main perspective application, flexible screens with high resolution.

\section{References}

[1] Burghignoli P., Lovat G., Capolino F., Jackson D.R., Wilton D.R.: Radiation from Elementary Sources in the Presence of Wire-Medium Slabs: Physical Mechanisms and Full-Wave Analysis. Proceedings of XVI Riunione Nazionale di Elettromagnetismo, Genova 2006, 113-116.

[2] Engheta N., Ziolkowski R.W.: Metamaterials: Physics and Engineering Explorations. John Wiley \& Sons Inc. 2006.

[3] Kalteneker K.J. et al.: Ultrabroadband Perfect Imaging in Terahertz Wire Media Using Single-Cycle Pulses. Optica 3(5)/2016, 458-464.
[4] Kosulnikov S., Vovchuk D., Nefedov I., Tretyakov S., Simovski C.: Broadband Power Transfer through a Metallic Wire Medium Slab. Proceedings of URSI International Simposium on Electromagnetic Theory (EMTS) 2016.

[5] Mirmoosa M.S.: Wire Media for Enhancement of Radiative Heat Transfer and Spontaneous Emission. PhD Thesis at Aalto University, 2017.

[6] Pendry J.B.: Negative Refraction Makes a Perfect Lens. Physical Review Letters 85 (18)/2000, 3966-3969.

[7] Rotman W.: Plasma simulation by artificial and parallel plate media. IRE Transactions on Antennas and Propagation 10 (1)/1962, 82-95.

[8] Sihvola A.: Metamaterials in electromagnetic. Physical Review Letters 85 (18)/2000, 3966-3069.

[9] Simovski C.R., Belov P.A., Atrashchenko A.V., Kivshar Yu.S Wire Metamaterials: Physics and Applications. Advanced Materials 24/2012, 4229-4248.

[10] Smith D.R., Padill W.J., Vier D.C., Nemat-Nasser S.C., Schultz S. Composite medium with simultaneously negative permeability and permittivity. Physical Review Letters 84/2000, 4184-4187.

[11] Veselago V.G.: Electrodynamics of substances with simultaneously negative electrical and magnetic permeabilities. Sov. Phys. Usp. 10/1968, 5-13.

[12] Vovchuk D., Kosulnikov S., Nefedov I., Tretyakov S., Simovski C.: MultiMode Broadband Power Transfer through a Wire Media Slab. Progress in Electromagnetics Research 154/2015, 171-180

[13] Zheludev N.I., Kivshar Yu.S.: From metamaterials to metadevices. Natural Materials 11/2012, 917-924.

\section{Ph.D. Dmytro Vovchuk}

e-mail:dimavovhuk@gmail.com

Assistant of professor at Radio Engineering and Information Security Department of Yuriy Fedkovych Chernivtsi National University. Research field includes metamaterials for the radio devices applications. Author of more than 10 publications.



Ph.D. Serhii Haliuk

e-mail: galiuk@inbox.ru

Assistant of professor at Radio Engineering and Information Security Department of Yuriy Fedkovych Chernivtsi National University. Research field covers the development of the different components of hidden communication systems. Author of more than 20 publications.

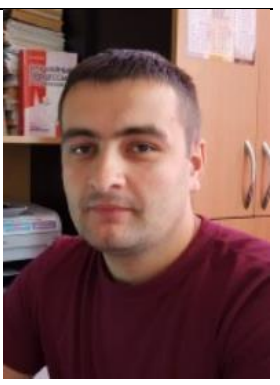

Prof. Leonid Politansky

e-mail: rt-dpt@chnu.cv.ua

Yuriy Fedkovych Chernivtsi National University. D.Sc. (technical), Professor, Head of the Department of Radio Engineering and Information Security. Research interests: physical processes in semiconductor devices, radio engineering devices and means of telecommunications. Author of nearly 200 publications in this research area.

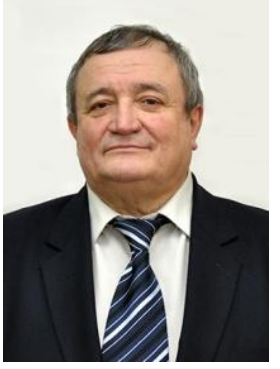

otrzymano/received: $10.10 .2017 \quad$ przyjęto do druku/accepted: 15.02 .2018 